\title{
Selected Reference Books of 1976-77
}

T

HIS ARTICLE continues the semiannual series originally edited by Constance $\mathrm{M}$. Winchell. Although it appears under a byline, the list is a project of the Reference Department of the Columbia University Libraries, and notes are signed with the initials of the individual staff members. ${ }^{1}$

Since the purpose of the list is to present a selection of recent scholarly and general works of interest to reference workers in university libraries, it does not pretend to be either well balanced or comprehensive. A brief roundup of new editions of standard works, continuations, and supplements is presented at the end of the column. Code numbers (such as AA297, BD202) have been used to refer to titles in the Guide to Reference Books. ${ }^{2}$

\section{LIBRARY RESOURCES}

East Central and Southeast Europe: A Handbook of Library and Archival Resources in North America. Paul Horecky, chief ed., David H. Kraus, assoc. ed. Santa Barbara, Calif., Clio Pr., [1976]. 467p. \$35.75. (Joint Committee on Eastern Europe. Publ. ser., 3) LC 76-28392. ISBN 0-87436-214-8.

This valuable survey of resources of some forty university libraries, archives, and research institutes "is intended to provide scholars, librarians, students and researchers with a basic reference tool for the study of .... essential collections.... in the United States and Canada, by outlining the profiles of these collections and offering broad guidance to their subject and area

1. Rita Keckeissen, Anita Lowry, Eileen McIlvaine, Mary Ann Miller, Doris Ann Sweet; Lehman Library: Diane Goon.

2. Eugene P. Sheehy, Guide to Reference Books (9th ed.; Chicago: American Library Assn., 1976).
contents."-Foreword. Countries covered are Albania, Bulgaria, Czechoslovakia, East Germany, Greece, Hungary, Poland, Romania, and Yugoslavia, with focus on the humanities and the socioeconomic and political sciences. Entries are arranged alphabetically by institution, with major collections described in essays as long as 5,000 words; other collections of substantial area strength are covered in shorter, less detailed reports. Essays include bibliographic information on important works and are signed by the contributor. An added feature is the general information that precedes a collection description, indicating organization, access, photocopying services, special catalogs, and publications that deal with the resources concerned. An "area and subject guide" serves as an index.-R.K.

\section{DISSERTATIONS}

Jacobs, Phyllis M. History Theses 1901-70: Historical Research for Higher Degrees in the Universities of the United Kingdom. [London], Univ. of London, Inst. of Historical Research, 1976. 456p. £4.50. LC 76-380809. ISBN 0-901179-34-5.

This is an attempt to provide a comprehensive list of theses "completed and approved" in United Kingdom universities for doctor's and master's degrees and also for the degree of B. Litt. Although regularly published lists of theses have been issued by the Institute of Historical Research from 1920 to date (Guide DC187), the compiler went beyond a mere cumulation of the printed lists, attempting to verify citations, correct errors, and winnow out works that may have been listed as completed but which were, in fact, never approved. More than 7,600 entries are presented in a classed arrangement, with separate author and subject indexes. Spot checking indicates that this volume includes many citations not 
found in the "Social Sciences and Humanities" volume of the Retrospective Index to Theses of Great Britain and Ireland, 1716-1950 (Santa Barbara, Calif., Clio Pr., 1976). Unfortunately, this is "not a list of theses which are necessarily available for consultation, since in nearly all British universities it is only in relatively recent years that students have been required to place a copy of their work on deposit."-Introd. A list of the universities represented would have been a worthwhile addition to the bibliography.-E.S.

\section{RELIGION}

Modern Concordance to the New Testament. Ed. and rev. following all current English translations of the New Testament by Michael Darton. Garden City, N.Y., Doubleday, [1976]. 786p. \$18.25. LC 75-34831. ISBN 0-385-07901-X.

"Based on the French Concordance de la Bible, Nouveau Testament produced under the aegis of the Association de la Concordance française de la Bible."-title page.

Founded on a French original, but completely revised and edited in English, this new concordance is designed to lead the student to the Greek text of the New Testament that lies behind modern English translations. To achieve this end, a subject presentation is used. More than 300 alphabetically arranged "themes" (i.e., groups of related words, such as "Hear-Listen-Learn") are listed as main headings, each set subdivided by Greek root, according to sense. Each subdivision is headed by the transliterated Greek term, and in the translated English verses that follow, the word used to render the Greek is italicized. This arrangement draws together all texts that translate a single Greek word and presents in close proximity texts that translate closely related Greek words. Texts quoted are from the Jerusalem Bible. An index of English words "used in the New Testaments of all English-language Bibles in wide use" ( $p$.xiii) refers to the keywords of the headings and subheadings under which a word is to be found. Similarly, the Greek word index refers the user to the English headings under which texts translating the Greek term are to be found. There is an index to proper names and a list of Greek roots.

An elaborate set of symbols, abbreviations, and numbers, as well as a variety of typefaces used to indicate headings and subheadings, initially complicate use of the work, but these incorporate so much information that the serious student will find the scheme effective once it is mastered. - R.K.

Novae concordantiae bibliorum sacrorum iuxta vulgatam versionem critice editam quas digessit Bonifatius Fischer OSB. [Stuttgart-Bad Cannstatt], FrommannHolzboog, [1977]. 5v. DM2000. ISBN 3-7728-0638-4.

Made possible by the use of electronic data processing techniques at the University of Tübingen, this Vulgate concordance is not a revision of any earlier work but a new compilation based on the recent critical Stuttgart edition of the text, Biblia sacra iuxta vulgatam versionem ... (Stuttgart, Würtembergische Bibelanstalt, 1975. 2v.). All words of that edition, including variants, with the exception of twenty-two common prepositions and pronouns, are included. All inflected forms of a word are grouped under a single heading, the basic form of the word, with Biblical texts ranged according to book and chapter regardless of form of word in the verse cited. The text of the Apocryphal books that form the appendix of the Stuttgart Vulgate is also covered by the concordance. The preface-in Latin, German, French, and English-explains details of arrangement and use. Two lists, "Series librorum et testium" and "Index codicum et editionum quibus usi sunt editores vulgatae," attest to the range of scholarly research of the Stuttgart text and the resulting concordance. Typeface is small, spacing is good, and the doublecolumned page is readily legible.-R.K.

Williams, Ethel L., and Brown, Clifton F. The Howard University Bibliography of African and Afro-American Religious Studies, with Locations in American Libraries. Wilmington, Del., Scholarly Resources, [1977]. 525p. \$24.95. LC 765604. ISBN 0-8420-2080-2.

This is an ambitious bibliography of more than 13,000 books, periodical articles, and parts of books designed to be comprehen- 
sive but "in no way [a] definitive" work covering African, Afro-Caribbean, and Afro-American religious studies. Materials are grouped in five main divisions: African heritage; Christianity and slavery in the New World; black religious life in the Americas; the civil rights movement; and the contemporary religious scene. Each section is subdivided by geographical area or church group, as appropriate. Within a section, materials are listed alphabetically by author, with at least one American library location indicated. There is a list of manuscript collections and their locations, an appendix of biographies and autobiographies, and an author index. No standards for inclusion are mentioned, and works included range from the scholarly to popular accounts appearing in national weeklies.-R.K.

\section{LITERATURE}

Anglo-Irish Literature; A Review of Research. Ed. by Richard J. Finneran. New York, Modern Language Assoc. of America, 1976. 596p. $\$ 18 ; \$ 10$ pa. LC 74-31959. ISBN 0-87352-252-4.

Finneran's volume makes a welcome addition to that list of MLA-sponsored "reviews of research" that includes Fisher's Medieval Literature of Western Europe (Guide BD6) and Faverty's Victorian Poets (Guide BD483), etc. As in those works, chapters by specialists survey and evaluate the scholarship of the field, pointing out lacunae and indicating areas where further research is needed. General works are considered in the opening essay, then follow chapters on nineteenth-century writers Oscar Wilde, George Moore, Bernard Shaw, W. B. Yeats, J. M. Synge, James Joyce, "Four revival figures [Lady Gregory, AE, Gogarty, James Stephens]," Sean O'Casey, and modern drama. Focus is on "writers of Anglo-Irish background whose careers have been completed and who have been the subject of a substantial body of published research. A liberal definition of 'background' accounts for the inclusion of Wilde and Shaw, whose credentials are otherwise open to some debate. The other criteria explain the lack of any detailed discussion of writers such as Beckett, Clarke, Colum, O'Faolain, and many others."-
Pref. The index includes the names of critical authors and biographers. - E.S.

Freudenthal, Juan R., and Freudenthal, Patricia M. Index to Anthologies of Latin American Literature in English Translation. Boston, G. K. Hall, [1977]. 199p. \$15. LC 76-40964. ISBN 0-8161-7861-5.

With entries for 1,122 Latin American authors from Abril to Zuccolotto, this index provides a key to a rich and varied world of Latin American literature in English translation. This world includes fiction, poetry, drama, and nonfiction (essays and speeches) by Spanish-American and Brazilian authors born during or after 1850. Unfamiliar names as well as familiar ones are listed in the "Index to Anthologies" section, where they are arranged alphabetically and followed by dates, country of origin, and the citations to the individual works. Citations are grouped by genre, then listed alphabetically by English title; for each, the name of the translator (where known) and appearance in one or more of the 116 anthologies are given. The careful attention to spelling and form of entry for authors' names and to crossreferences from pseudonyms is welcome, though some inconsistencies in citations for individual titles can be noted; unfortunately, original Spanish or Portuguese titles are not indicated. The volume also includes an annotated bibliography of the anthologies consulted; a selective, annotated bibliography of English-language works on Latin American literature; and two indexes: a "Translator Index" and a "Geographic Index." The work is an admirable response to the growing interest in Latin American literature and is an especially valuable aid for the English-speaking undergraduate or the nonspecialist. - A.L.

Martin, Angus; Mylne, Vivienne G; and Frautschi, Richard. Bibliographie du genre romanesque français, 1751-1800. London, Mansell; Paris, France, Expansion, 1977. 529p. il. $\$ 82.50$. ISBN 0-7201-0379-7.

For purposes of this bibliography the "genre romanesque" is defined as including novels, short stories, and other prose writings (such as dialogues) that embody some element of narrative fiction. In general the 
plan and scope of the bibliography follow that of S. P. Jones' A List of French Prose Fiction from 1700 to 1750 (Guide BD778), except that the new work includes French translations of works originally published in other languages and also new editions of older works. As in Jones, the arrangement is chronological, then alphabetical by author, with an index of authors and titles; there is a separate section of "rééditions" for each year. In addition to information on variant editions, serialization in periodicals, and library locations, there are often useful notes on form (e.g., letters, first-person narrative, pseudo-biography) and content. The Bibliothèque Nationale, the British Museum, and the Bibliothèque de l'Arsenal (Paris) account for the bulk of the library locations, though many more libraries are represented here than in Jones. Handsomely produced, the bibliography encompasses some 6,750 entries; taken with the Jones volume and Ralph C. Williams' Bibliography of the Seventeenth-century Novel in France, bibliographic coverage of French prose fiction is now provided from 1600 to 1800.-E.S.

\section{THEATER ARTS}

Lyday, Leon F., and Woodyard, George W. A Bibliography of Latin American Theater Criticism, 1940-1974. Austin, Inst. of Latin American Studies, Univ. of Texas at Austin, 1976. 243p. $\$ 5.95$ pa. (Guides and bibliographies ser., 10) LC 76-45126. ISBN 0-292-7017-7.

Covering a thirty-five-year period that "corresponds to the establishment and development of a truly national theater movement in most areas of Latin America" (Introd.), this useful bibliography lists some 2,300 items of Latin American theater criticism. Books, periodical articles (including book reviews), and doctoral dissertations are entered in an alphabetical arrangement by critical author, with subject index. A country or regional designation in the right-hand margin provides a geographical approach that is not generally duplicated in the index, although there is a country breakdown under certain subject entries, such as "experimental theater" or "theater groups." Brief explanatory notes or contents notes are provided for some items. A separate listing of bibliographies of Latin American theater precedes the numbered entries-E.S.

\section{SOCIOLOGY}

Milden, James Wallace. The Family in Past Time: A Guide to the Literature. New York, Garland Pub., 1977. 200p. \$19. (Garland reference library of social science, v.32) LC 76-24767. ISBN 0-82409910-9.

Family history as a field for the social scientist is a relatively new area, interdisciplinary in nature, and thus providing a real challenge for the pioneering bibliographer; Milden has made a significant beginning. By "family history," he refers not to genealogy and heraldry "but to the growing body of literature dealing with the social history of the family and the family life of ordinary people in past time."-Pref. An introductory essay provides an overview and stateof-the-art report on family history, and the first chapter lists works on methodology and theory. The rest of the bibliography is arranged geographically, chronologically, and topically, the three main sections covering the family in European, American, and non-Western history. Worldwide in scope but restricted to English-language writings, it includes books, articles, and unpublished papers and theses written prior to 1976 . The cut-off date roughly corresponds to the date of the change of title of the History of Childhood Quarterly to Journal of Psychohistory (Summer 1976) - testimony to the rapidly evolving and converging activities of family historians. - M.A.M.

\section{Miller, Wayne Charles. A Comprehensive} Bibliography for the Study of American Minorities. New York, New York Univ. Pr., 1976. 2v. (1,380p.) \$85. LC 76381493. ISBN 0-8147-5373-6.

Now there is a single work that should "leap to mind" when information is sought by the beginning or advanced student about any ethnic group in the United States. It is one designed to encourage a crossdisciplinary and comparative approach, being arranged according to area of origin, specific group, discipline, and topical subject. Each ethnic group (e.g., French- 
Americans, Finnish-Americans) is introduced by a guide to its "American experience": a thumbnail history and bibliographic essay. Then follows a list of bibliographies, a list of periodicals and newspapers published by the ethnic community or by organizations concerned with their affairs, and, finally, the topical references. Comprehensiveness of the latter is determined by the amount of attention the group has received from scholars and writers. Thus, widely studied groups will be represented mainly by books, while others will include many articles and pamphlets in addition to books. To accommodate differences in minority experience, some flexibility in arrangement has been observed; for example, the Asian-American sociology sections include the heading "Prejudice" while the Eastern European sections do not. The bibliography is limited to English-language materials. There is no index, but with careful use the work will provide a fruitful approach to the study of common and unique aspects of America's ethnic and native minorities.M.A.M.

Prucha, Francis Paul. A Bibliographical Guide to the History of Indian-White Relations in the United States. Chicago, Univ. of Chicago Pr., [1977]. 454p. $\$ 17.50$. LC 76-16045. ISBN 0-22668476-8.

A well-researched and well-constructed guide to the sources and literature of any area of study soon finds grateful users and may indeed generate further studies in that field. Prucha's guide to primary and secondary sources on Indian-white relations in the United States falls into this praiseworthy category of bibliography. The scope of the volume encompasses historical material from the British colonial period through the twentieth century; material on early Spanish-Indian relations is not covered.

Part I, "Guides to Sources," provides an overview of primary sources available to researchers and cites guides to archives, manuscripts, government documents, special collections, newspapers, oral history projects, maps and travel accounts, as well as other bibliographies that cover or touch on the topic of Indian-white relations. Part II, "Classified Bibliography of Published
Works," includes listings of books, articles, dissertations, and selected government documents. The classification scheme is basically topical, with chapters such as "Indian Affairs/Indian Policy," "Trade and Traders," "Land and the Indians," and "Missions and Missionaries." When the quantity of listings warrants it, chapters are subdivided into chronological segments, and these often feature a section of "current comment" wherein writings contemporary to the period are cited. An author/subject index rounds out this excellent guide. -D.A.S.

Research Publications Inc. Bibliography and Reel Index: A Guide to the Microfilm Edition of United States Decennial Census Publications, 1790-1970. Woodbridge, Conn., Research Publs., 1975. 276p. \$45. LC 75-33819. ISBN 0-89235-003-2.

Published in conjunction with the Research Publications microform edition of United States decennial census publications, this volume serves primarily as a guide to the contents of that set but may prove to have broader utility. Based largely on information available in Henry Dubester's Catalog of United States Census Publications, 1790-1945 (Guide CG60) and the U.S. Bureau of the Census' Catalog of Publications, 1946-72 (Guide CG59), it by no means supersedes those publications, since it does not include nondecennial census material, it does not provide subject access, nor are its annotations nearly as detailed. Arrangement is by census year, subarranged by census category (population, housing, manufactures, etc.). The simple and straightforward item numbering system is based on that of the University of Texas Population Research Center's International Population Census Bibliography, v.4, "North America" (Guide CG13). A crossindex is provided from Dubester item numbers.

A unique contribution made by the bibliography arises from the fact that, in producing the microform edition, Research Publications attempted to avoid duplication in filming. Hence, when a preliminary report was superseded by a final report, when an item published separately was also issued as part of a larger item, or if a more complete or corrected version of a report was issued, 
only the latter was filmed. The bibliography notes both items and their relationship. Much, but not all, of this information can be obtained in Dubester and the Bureau of the Census Catalog. In one case noted, a publication cited in a 1960 census report is identified here as "not yet published," a piece of information otherwise difficult to come by. In short, this bibliography is essential for those libraries holding the microform edition, but libraries with census material in other forms and which deal with census research problems may find it helpful-if they can afford the high price.-D.A.S.

\section{ECONOMIC HISTORY}

Cortés Conde, Roberto, and Stein, Stanley J., eds. Latin America; A Guide to Economic History, 1830-1930. Berkeley, Univ. of Calif. Pr., 1977. 685p. \$35. LC 74-30534. ISBN 0-520-02956-9.

"Sponsored by the Joint Committee on Latin American Studies of the American Council of Learned Societies and the Social Science Research Council and by the Consejo Latinoamericano de Ciencias Sociales."-t.p.

The fruit of long planning and cooperative scholarly effort, this impressive bibliography offers a carefully selected list of sources for the study of Latin American economic history of the period 1830-1930. A section for general bibliography is followed by a section for each of six countries: Argentina, Brazil, Chile, Colombia, Mexico, and Peru. Each country section begins with an interpretive essay, and each ensuing bibliography is topically subdivided under ten major headings: (1) general and reference works; (2) demography, manpower, and living conditions; (3) structures and institutions; (4) macroeconomic growth and fluctuation; (5) foreign trade and investment; (6) regional economy; (7) agriculture, ranching, forestry; (8) industry: factory and artisan; (9) extractive industry; (10) transport, public utilities, and services. Introductory essays and annotations are in the language of the contributors of the section.

The more than 4,500 items run heavily to books, but some periodical articles are included, as are references to runs of peri- odicals of special interest. Annotations are often evaluative as well as descriptive. Except in the Peru section, library locations are given for most items. There is an author index and one of periodicals, but none of specific subjects. A lengthy introduction recounts the history of the project, explains the choice of inclusive dates, and offers a synthesis of the interpretive essays. - E.S.

\section{POLITICAL SCIENCE}

Greenstein, Fred I. [and others]. Evolution of the Modern Presidency: A Bibliographical Survey. Washington, D.C., American Enterprise Institute for Public Policy Research, [1977]. Unpaged. \$4.75 pa. (Studies in political and social processes; AEI studies, 153) LC 77-8022. ISBN 0-8447-3251-6.

It is the premise of the authors that "no institution of American government has changed so drastically and with such profound consequences for American society as has the Presidency" (Introd.) since 1932, in terms of enlarged role expectations, expansion of the office and its advisers, and consequent expansion in presidential power and policy initiation and implementation. In an effort to facilitate research on the modern presidency, they have produced this volume. It is a partially annotated, computerproduced, classified list of more than 2,500 monographs, periodical articles, and government documents. The citations are grouped in twenty-one chapters covering reference sources, government publications, anthologies, general works on the presidency, presidential recruitment and personality, growth of the presidential staff, constituencies such as public opinion and other branches of government, powers and restraints, the vice-presidency, and attempts to reform the presidency. There are separate chapters on individual presidencies from Franklin D. Roosevelt to Gerald R. Ford, with sections on historical accounts and biographies, papers and memoirs, prepresidential background, advisers and advisory relations, and specific events, activities, and policies (e.g., the New Deal, Kennedy's assassination, and Watergate). Annotations are descriptive and very brief. The volume concludes with an author index. 
In his preface Greenstein promises new editions, presumably covering Carter and the more recent literature. If a detailed subject index could be provided, it would be a useful addition to this welcome, worthwhile, and refreshingly inexpensive work.-D.G.

\section{GEOGRAPHY}

Henze, Dietmar. Enzyklopädie der Entdecker und Erforscher der Erde. Graz, Akademische, Druck- u. Verlagsanstalt, 1975- . Lfg. 1- . 460 Sch. per Lfg. (In progress) LC 76-476118. ISBN 3-201-00912-1.

Contents: Lfg. 1-2, A-Bock.

On the evidence of these first fascicles, this is a very ambitious work. Not only is it international in scope, it covers from earliest to modern times, and the "explorers and discoverers" of the title include geographers, surveyors, travelers, military reconnaissance personnel, seafarers, merchants, and leaders of various scientific expeditions. The usual pattern of the entries is to present a very brief note on the subject's life, which is followed by an account of the person's explorations, discoveries, or special contribution to the field of geography. Assessment of that contribution frequently takes the form of quotation (sometimes at considerable length) from published sources. Most of the articles include a list of the biographee's own writings and of writings about the individual.-E.S.

\section{History AND AREA STUdIES}

Bayliss, Gwyn M. Bibliographic Guide to the Two World Wars; An Annotated Survey of English-language Reference Materials. London \& New York, Bowker, [1977]. 578p. \$30. LC 77-70292. ISBN 0-85935-013-4.

This is a "guide to the guides": a guide to reference books of importance for researchers on the First or Second World Wars. Arranged by type of reference work-general guides, bibliographies, directories, dictionaries and encyclopedias, periodical lists and indexes, biographies, etc.-the volume serves as a starting point for the study of a wide range of topics: economic, religious, and scientific, as well as military, diplomat- ic, and political. Bayliss is Keeper of the Department of Printed Books at the Imperial War Museum in London and thus is especially familiar with the materials he cites. He shares his knowledge with the researcher through descriptive annotations and through the introductory essays at the beginning of each section, evaluating the usefulness of the various works and pointing up publishing needs. Inasmuch as the author has experience with the needs of researchers and familiarity with a great collection of materials, it is to be regretted that he decided against including many foreignlanguage materials: a guide to the foreign sources is what many of us need most.

Books, pamphlets, some mimeographed lists, and important periodical articles published up to early 1976 are included. There are author, title, region or country, and subject indexes. Of almost 120 pages of index, the regional and subject indexes cover just 19 pages. Under "America" there are twenty-two lines of entry numbers, under "Britain," fifteen lines, and under "United States," twenty lines-all with no subdivisions. The author has done a useful service for us, but one wishes for just a little more. Finally, there is a complaint to the publisher: there is virtually no inner margin on the right-hand page, so that the book could never be satisfactorily rebound.-E.M.

Bonser, Wilfrid. A Prehistoric Bibliography. Extended and ed. by June Troy. Oxford, Blackwell, 1976. 425p. £25. ISBN 0-63117090-1.

Although it is the most recently published, this volume is the chronological predecessor of, as well as a companion to, the late Dr. Bonser's Romano-British Bibliography (1964; Guide DC162) and his Anglo-Saxon and Celtic Bibliography (1957; Guide DC161). The more than 9,000 entries include both books and periodical articles, with a preponderance of the latter, many of them drawn from British local history, archaeological, and antiquarian society publications. A topical arrangement under five main headings is employed: (A) men and methods in archaeology; (B) field archaeology; (C) specific sites; (D) material finds; (E) culture. Each main section is appropriately subdivided, and parts B, C, and D are fur- 
ther subdivided according to six geographical zones of the British Isles. There is an index of authors and subjects.-E.S.

Guide to Federal Archives Relating to Africa. Researched and comp. by Aloha South, [indexed and prep. by Michael Sims]. [Waltham, Mass.], Crossroads Pr., [1977]. 556p. \$65. LC 77-412.

Comp. and ed. by the National Archives and Records Service for the African Studies Association.

The National Archives and Records Service has provided this tool for mining the vast and rich store of Africa-related materials in the United States National Archives in Washington and in its various regional branches and presidential libraries. The volume thoroughly annotates the records and papers of forty-two divisions of the federal government, mostly material produced during the era of Western colonialism in Africa. Arrangement is according to the generating body (Congress, Department of Defense, Smithsonian Institution. etc.), subdivided by subsidiary agencies, by type of document, and, for State Department material, by country and subject. (State Department records account for nearly half the volume's space.) Each file's contents are annotated as to their nature, concerns, size, and arrangement, with mention of key names, events, and dates. All of this wellordered information is made accessible through five indexes: subjects, places, personal names, ships, and ethnic groups.

This is a careful work whose authors, seeing the blindness and prejudice toward Africa and Africans reflected in the language used in labeling and describing the people and their cultures, took steps to correct the "objectionable" terminology while not hampering access to the content of the records. - M.A.M.

- Matthews, Noel, and Wainwright, M. Doreen. A Guide to Manuscripts and Documents in the British Isles Relating to the Far East. Ed. by J. D. Pearson. Oxford, Oxford Univ. Pr., 1977. 182p. £17.50. ISBN 0-19-713591-9.

Mayer, Sydney Louis, and Koenig, William J. The Two World Wars; A Guide to Manuscript Collections in the United
Kingdom. London \& New York, Bowker, [1976]. 317p. \$30. LC 74-9187. ISBN 0-85935-014-2.

Over the last several years, surveys of archival material have appeared with increasing frequency (as witness the notes on the Horecky and Cook volumes in this article alone). Researchers are fortunate therein, and the two British surveys discussed below add to their riches.

Based on visits to the most likely repositories in Great Britain and Ireland, Matthews and Wainwright's guide calls attention to the important manuscripts in the Western languages relating to China, Japan, Korea, and the extreme eastern parts of the Soviet Union. The curators of the archives were given the opportunity to correct or add any information in the description of the archive, and Pearson added newer information drawn from the publications of the National Register of Archives. This is the third volume compiled by these specialists for the series sponsored by the School of Oriental and African Studies, and it is arranged by repository in much the same way as the earlier volumes for South and Southeast Asia (1965; Guide DE15) and for Africa (1971; Guide DD59). We can look forward to a fourth and final volume on the Near and Middle East.

Indexing is much fuller than in the Mayer and Koenig work noted below, though use of the volume would have been facilitated if the entries were numbered, making it easier for the user to locate the precise name or event on a two-column page crowded with names and events.

In order to "ease the path of students of the two world wars ... . and encourage them to embark on new studies of these two important events" (Introd.), Mayer and Koenig visited the important archives in Oxford, Cambridge, London, and Edinburgh and sent questionnaires to county and local record offices. The primary "military and naval records in the public domain as well as the diplomatic and political records which impinge directly on the course of the wars themselves" are the parameters the compilers set for themselves. They have briefly described, collection by collection, the contents of those archives that would be of most value to researchers, noting any re- 
strictions on use and any published guides. For the Public Record Office the approach is different, because the PRO itself has issued extensive guides; therefore, the compilers have made general statements and listed "some of the private office and deposited papers of public servants involved in the war in various capacities." No attempt was made to survey in depth the regimental museums, since a catalog of their holdings is in preparation by the National Army Museum.

Like the compilers' earlier work, European Manuscript Sources of the American Revolution (London, 1974), the volume is easy to use and has brief but lucid annotations. The indexing is serviceable, primarily citing personal or geographic names, with a few subject listings; the topical listings could well be more extensive.

Now we librarians have the responsibility of making all these guides widely known to researchers. - E.M.

\section{NEW Editions, SUPPlements, ETC.}

Three additional languages-Finnish, Hungarian, and Romanian-are included in the third edition of Jerrold Orne's The Language of the Foreign Book Trade (Chicago, American Library Assn., 1976. 333p. \$6.50; 2d ed. 1962, Guide AA297), bringing the total number of languages to fifteen.

Two new volumes of the Bibliografía uruguaya covering "Años 1969 a 1972 inclusive" have appeared (Montevideo, Biblioteca del Poder Legislativo, 1977. 2v., 408p.). As in the 1962-68 cumulation (Guide AA933), the alphabetical main entry listing is followed by indexes of subjects, titles, names, etc.

With the appearance of volumes two and three, the twelfth edition of The Reader's Adviser is now complete. Volume two, "The Best in American and British Drama and World Literature in English Translation" (New York, Bowker, 1977. 774p. \$25), was edited by F. J. Sypher and, as in the first volume (published 1974), each section is by a contributing editor with expertise in the field; volume three, "The Best in the Reference Literature of the World" (New York, Bowker, 1977. 1,034p. \$25), was edited by Jack A. Clarke.
Ulrich's Quarterly; A Supplement to Ulrich's International Periodicals Directory and Irregular Serials and Annuals (v.1, no.1, Spr. 1977; New York, Bowker. \$24/ yr.) provides a record of new serial titles, title changes, and cessations between issues of the biennial publications mentioned in the subtitle. Format follows that of the biennial volumes, and title indexes will cumulate in each issue throughout a volume.

Whereas C. Edward Wall's Periodical Title Abbreviations (Guide AE15) emphasized publications in the fields of language, literature, and linguistics, the scope of the second edition of that work as compiled by Leland G. Alkire, Jr. (Detroit, Gale, 1977. 436p. \$32) has been expanded to cover "science, the social sciences, the humanities, law, medicine, religion, library science, engineering, education, business, art, and many other fields." There are nearly 20,000 entries in the new edition of this very useful work.

Although coverage of Viewpoint: America's Syndicated Journalists on File (Glen Rock, N.J., Microfilming Corporation of America, 1976- . \$198/yr.) begins with 1976, changes and improvements are still being made in this comprehensive record of the newspaper columns of 100 carefully selected journalists. Beginning in 1977, the subscription price includes a monthly microform file (offered in a choice of microfilm or microfiche) of all columns of the selected writers and a monthly magazine that reprints in full about sixty representative columns from the previous thirty-to-forty-fiveday period together with subject and byline indexes to both the magazine and the microform file. Cumulative subject and byline indexes for 1976 have now been published, providing references to the microform edition and also to a hardbound volume entitled The Presidency, which constitutes the magazine edition for 1976. Some refinement of subject headings has been effected in recent monthly indexes and will, of course, be carried over into the annual cumulation.

The twelfth volume of Rosa Quintero Mesa's Latin American Serial Documents (Ann Arbor, Mich., University Microfilms International, 1977. 313p. \$19.95) is devoted to Venezuela. Like earlier volumes of the se- 
ries (Guide AG103), it shows "holdings in the United States and Canada for as many serial documents as could be identified ... from the time of the country's formation."-Introd.

Biographies of 556 persons, written by 480 contributors, make up "Supplement Five, 1951-1955" (New York, Scribner's, 1977. 799p. \$45) of the Dictionary of American Biography. Editor John A. Garraty's preface notes that "certain 'standard" facts not necessarily important for the individual ... [that were included in earlier supplements] for the benefit of sociologists and other scholars interested in collective biography" are generally omitted from this supplement. Such information, however, was gathered on data sheets that will be on file with the $D A B$ papers in the Library of Congress. An "Index Guide to the Supplements" provides a cumulative list of biographees treated in all five supplementary volumes.

Under the editorship of Joseph G. E. Hopkins, the second edition of the Concise Dictionary of American Biography (New York, Scribner's, 1977. 1,229p. \$30) has been expanded to include entries for all the biographees in the parent $D A B$ (Guide AJ41) and its first four supplements. It follows the plan and philosophy of the 1964 edition and provides about 16,000 sketches of persons who died prior to 1951 .

Although reset in smaller type (and, regrettably, printed on inferior paper), the text of the third edition of Manuel de Mendiburu's Diccionario histórico-biográfico del Perú (Lima, Editorial Arica, 1976- ) remains unchanged from the second edition of 1931-35 with the notes and additions of Evaristo San Cristóval (Guide AJ255).

Coverage of the two-volume Genealogies in the Library of Congress (Guide AK21) has been extended through publication of a "Supplement, 1972-1976" (Baltimore, Magna Carta, 1977. 285p. \$23.50). Also edited by Marion J. Kaminkow, the supplementary volume includes numerous older works as well as publications of the 1972-76 period.

Interpretations and explanations of the short fiction of more than 850 writers since 1800 are listed in the third edition of War- ren S. Walker's Twentieth-Century Short Story Explication (Hamden, Conn., Shoe String Pr., 1977. 880p. \$25). The volume cumulates the references from the second edition and its two supplements (Guide BD202) and extends the period of coverage through 1975. In the interest of saving space, a slightly different arrangement and an abbreviated form of citation have been adopted for this edition.

With the appearance of volume five, "Index" (Cambridge, University Pr., 1977. 542 col. \$21.50), the New Cambridge Bibliography of English Literature (Guide BD376) is now complete. Compiled by J. D. Pickles, this is "a general index to all four volumes, listing primary authors and major anonymous works, as well as certain headings from the Bibliography as a whole."-Pref. It is wider in scope than the provisional indexes in the individual volumes and "includes titles of periodicals from sections devoted to Newspapers and Magazines, as well as the names of their editors and proprietors; and the names of certain minor authors listed under such sections as Travel and Sport. .... It also lists foreign writers from the comparative sections on Literary Relations."

Wolfgang Stammler's Die deutsche Literatur des Mittelalters: Verfasserlexikon (Guide BD637) has begun to appear in a second edition (Lfg. 1, A-Altzeller. Berlin, de Gruyter, 1977) under the editorship of Kurt Ruh. Revised and expanded in the light of new scholarship, the new work will adhere to the plan and principles of the first edition and features signed articles with bibliographies. The set is to be complete in six volumes of four Lieferungen each, with two to three parts to be published per year.

The latest addition to Ungar's "Library of Literary Criticism" series is Modern French Literature (New York, Ungar, 1977. 2v. $\$ 55)$, edited by Debra and Michael Popkin. Like other volumes in the series (e.g., Guide BD419), this is a collection of excerpts from critical writings; all selections are presented in English, many of them having been translated from the French specifically for this compilation. The 168 modern French authors treated are those considered to be "the ones who are most 
read, taught, and written about today in France, the United States, and Britain."Introd.

Notable Names in the American Theatre (Clifton, N.J., James T. White \& Co., 1976. $1,250$ p. $\$ 69)$ represents a "new and revised edition" of The Biographical Encyclopaedia and Who's Who of the American Theatre (Guide BG66). Most sections of the earlier volume have been updated and expanded; a new section listing play premieres throughout America, 1968-73, has been added; and the "who's who" section (herein designated as "Notable Names ....") again makes up the bulk of the volume.

Fully reset for the first time in the work's long history, the sixteenth edition of Who's Who in the Theatre (London, Pitman; Detroit, Gale, 1977. 1,389p. $\$ 50$ ) aims to present "the fullest possible coverage of the major personalities of today's theatre, with several thousand existing biographies brought up to date and several hundred more added." Features of earlier editions (see Guide BG68) such as the London and New York playbills are extended or updated.

Information on 2,818 foundations "qualifying by definition, size of assets, or by aggregate annual giving" (Introd.) appears in the sixth edition of The Foundation Directory (New York, Foundation Center, 1977. 661p.; distr. by Columbia Univ. Pr. \$36). It follows the plan and format of the fifth edition (1975; Guide CA56) and is again under the editorship of Marianna $\mathrm{O}$. Lewis.

The seventeenth issue of the Encyclopedia of Social Work (Washington, D:C., National Assoc. of Social Workers, 1977. 2v. \$40) follows the plan of the previous edition (1971; Guide CC32), and evidences thorough review and revision: 129 articles were rewritten; 23 were subject to more limited revision; and only 2 remain completely unchanged. In addition, forty new articles (including such topics as child abuse, citizen participation, preventive social work, multi- parent families) and eight new biographies have been incorporated into the work.

Although Lorna M. Daniells' Business Information Sources (Berkeley, Univ. of Calif. Pr., 1976. 439p. \$14.95) "was begun as a revision of Edwin T. Coman's Sources of Business Information [rev. ed. 1964; Guide CH93] . . . and covers some of the same material, it is, in fact, a completely different work."-Pref. A worthy successor to the Coman compilation, it is a selected, annotated list of business books and reference sources for the businessman, the business student, and the librarian.

Gerard L. Alexander's Guide to Atlases Supplement: World, Regional, National, Thematic (Metuchen, N.J., Scarecrow, 1977. 362p. \$14) is an international listing of atlases published during the 1971-75 period, with some entries from the years 1950-70 for items overlooked in the basic compilation (Guide CL165). It follows the arrangement of the main volume and includes author and publisher indexes.

Two additional volumes of Chris Cook's useful Sources in British Political History, 1900-1951 have now appeared. Volumes three and four are subtitled "A Guide to the Private Papers of Members of Parliament" (London, Macmillan, 1977. £15 per v.) and, as far as possible, locate and briefly describe "the surviving private papers of all Members of Parliament from the General Election of September 1900 to the fall of the Atlee Government in the election of October 1951."-Introd. Dispersal, destruction, or failure to locate papers of a given M.P. are noted.

The 1955-57 volume of Writings on British History (London, Univ. of London, Inst. of Historical Research, 1977. 362p. $\$ 28.20$ ) is now available. Edited by John M. Sims and Phyllis M. Jacobs, it lists nearly 6,300 books and articles on the history of Great Britain to 1939. Plan and arrangement follow that of earlier volumes of the series (Guide DC186).-E.S. 


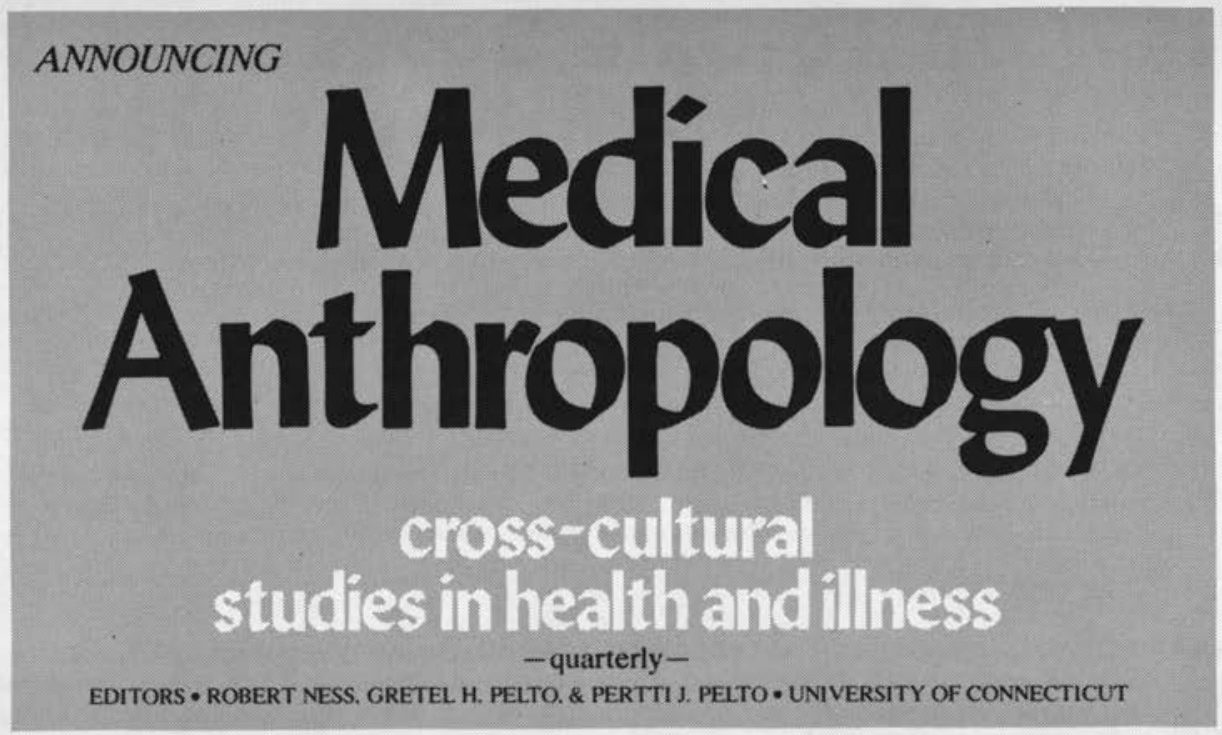

Medical Anthropology explores the relationships between illness and human social life as well as the cross-cultural similarities and differences in the way people cope with health problems.

Medical Anthropology will offer sophisticated studies on topies including:

Health care and healing behavior in nonWestern and Western societies

Population, natality, and family planning

Nutritional anthropology

Studies of health care systems, especially those involving special culture, social, or ethnic factors

Palaeopathology, Biogenetic \& Biocultural research, both U.S. and cross-cultural
Volume One, 1977, Includes Papers On:

Espiritismo: health-seeking behavior among Puerto Ricans

Fertility and high altitude stress

Comanche ghost sickness: a biocultural interpretation

Palaeopathology of degenerative knee disease Psychosocial concomitants of thalassemia Lay competence in the diagnosis of pregnancy

This quarterly provides an important crosscultural context to the concerns of nurses, physicians, biological scientists, and other professionals in health-related fields, as well as anthropologists.

\section{Medical Anthropology Subscription Order Form}

$\begin{array}{cl}\quad \square \text { individual } & \square \text { Check enclosed } \\ \text { Enter my } \square \text { institutional subscription(s) for } — \text { year(s) to: } & \square \text { Please bill me }\end{array}$

\section{Institutions 1 YEAR $\$ 25.00 \quad 2$ YEARS $\$ 46.00 \quad 3$ YEARS $\$ 68.00$}

Subscriptions are on a volume-year basis only. Subscribers outside the United States, please add $\$ 3.00$ per year for surface mail. Shipment will be made upon full payment in advance.

Name (please type or print)

Address

City, State, Zip REDGRAVE PUBLISHING COMPANY, 430 Manville Road, Pleasantville, New York 10570 


\section{NEW Up-To-Date Books From Noyes Data}

NOYES DATA has developed two new techniques of vital importance to those who wish to keep abreast of rapid changes in technology and business conditions: 1) our advanced publishing systems permit us to produce durably-bound books within a few months of manuscript acceptance; 2) our modern processing plant ships all orders on the day after they are received.

\section{HARDCOVER BOOKS-EARLY 1978}

HANDBOOK OF CATALYST MANUFACTURE by M. Sittig: This book concentrates on practical examples for all those hydrocarbon-only reactions which benefit by the presence of catalytic substances. Methods of manufacturing, handling and recovering such catalysts are described in minute detail. A total of $\mathbf{4 1 5}$ recent U.S. patents has been excerpted for this purpose. ISBN 0-8155-0686-4; \$48

THERMAL INSULATION-RECENT DEVELOPMENTS by J.B. Dillon: This very timely book provides a detailed, practical view of the research and product developments, as well as the actual applications technology of insulation systems reducing the effects of climatic heat and cold. In a very significant way, this type of energy saving can counteract our negative balance of payments position. ISBN 0-8155-0687-2; \$39

FRICTION MATERIALS-RECENT ADVANCES by L.B. Newman: Friction materials that are used in brake linings and clutches have severe performance requirements. The emphasis today is on organically bonded linings. For modern disc brakes there are many semimetallic compositions. The book provides several hundred formulations answering most design requirements. ISBN 0-8155-0688-0; \$36

MAGNETOHYDRODYNAMIC ENERGY FOR ELECTRIC POWER GENERATION edited bY R.F. Grundy: The production of electricity by magnetohydrodynamic (MHD) processes is classed as direct energy conversion. In an MHD generator the expanding hot ionized gas or plasma passes a magnetic field to produce electricity. The potential of producing cheaper electricity by MHD is explored. ISBN 0-8155-0689-9; \$36

CHEMICALS FROM PULP AND WOOD WASTE-PRODUCTION AND APPLICATIONS by G.T. Maloney: While wood and wood wastes are not subject to depletion, processing into chemicals is considerably more complex and costly than production of the same chemicals from petroleum feedstocks. Yet nowadays, with the price of petroleum going higher and higher, it appears that chemicals from wood wastes can be produced at competitive prices in the near future. ISBN 0-8155-0690-2; \$42

HYDROGEN MANUFACTURE BY ELECTROLYSIS, THERMAL DECOMPOSITION AND UNUSUAL TECHNIQUES edited by M.S. Casper: This book deals with alternate sources and processes for the production of hydrogen. Today, hydrogen is made mainly from natural gas end by petroleum refining. These sources are dwindling, and it is an appropriate time to develop other means for obtaining this essential energy carrier. ISBN 0-8155-0691-0; \$39

ENHANCED OIL RECOVERY-SECONDARY AND TERTIARY METHODS edited by M.M. Schumacher: This is a book about greater oil recovery by succeeding methods; the possible techniques and their present or future capabilities for extracting more petroleum from oil fields after primary production. ISBN 0-8155-0692-9; \$32

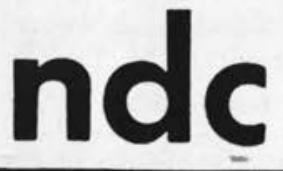

\section{NOYES DATA CORPORATION} NOYES BUILDING, PARK RIDGE, NEW JERSEY 07656 